\title{
HUBUNGAN MEROKOK DENGAN KADAR GLUKOSA DARAH MAHASISWA FAKULTAS HUKUM UNIVERSITAS ISLAM AL-AZHAR TAHUN 2019
}

\author{
Deny Sutrisna Wiatma*, Muhlisin Amin** \\ Fakultas KedokteranUniversitas Islam Al-Azhar \\ Jl. Unizar No. 20 TuridaMataram \\ Email : denz.louhan@gmail.com
}

\begin{abstract}
ABSTRAK
Latar Belakang :Rokok sangatlah berbahaya bagi kesehatan, salah satu kandungannya yakni nikotin telah diketahui dapat menjadi faktor resiko kejadian diabetes, nikotin dapat merusak sel $\beta$ pankreas dan menghambat insulin.

Tujuan :untuk mengetahui hubungan merokok dengan kadar glukosa darah mahasiswa Fakultas Hukum Universitas Islam Al-Azhar Mataram tahun 2019.

Metode Penelitian : Populasi pada penelitian ini adalah 52 orang mahasiswa perokok aktif Fakultas Hukum Universitas Islam Al-Azhar periode 2015-2019, sampel diambil dengan teknik total sampling yakni jumlah sampel sama dengan jumlah populasi, dan menggunakan metode preeksperimental design dengan rancangan non equivalent control group, hasil pada penelitian ini selanjutnya di analisis dengan uji Chi-Square.

Hasil : Hasil yang didapatkan dari uji Chi-Squarediperoleh nilai signifikan dengan rerata kadar glukosa darah pretest dan posttest kelompok eksperimen adalah 107,73 mg/dL dan 112,65 $\mathrm{mg} / \mathrm{dL}$ sedangkan pada kelompok kontrol adalah 123,27 mg/dL dan 112,40 mg/dL serta didapatkan $p$ value $0,001(\mathrm{P}<0,05)$. darah.

Kesimpulan :Terdapat Hubungan yang Signifikan antara merokok dengan kadar glukosa
\end{abstract}

Kata Kunci : Merokok, Nikotin, Glukosa Darah.

\section{PERDAHULUAN}

Rokok menurut peraturan pemerintah no 109 tahun 2012 adalah salah satu produk tembakau yang dimaksudkan untuk dibakar dan dihisap dan atau dihirup asapnya, termasuk rokok kretek, rokok putih, cerutu atau bentuk lainnya yang dihasilkan dari tanaman nicotiana tobacum, nicotiana rustica, dan spesies lainnya atau sintesisnya yang asapnya mengandung nikotin dan tar, dengan atau tanpa bahan tambahan (Depkes.2016).

Persentase penduduk dunia yang mengkonsumsi tembakau berdasarkan The

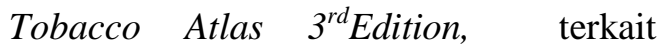
didapatkan sebanyak $57 \%$ pada penduduk Asia dan Australia, 14\% pada penduduk
Eropa Timur, $12 \%$ penduduk Amerika, 9\% penduduk Eropa Barat dan 8\% pada penduduk Timur Tengah serta Afrika. Sementara itu ASEAN merupakan sebuah kawasan dengan 10\% dari seluruh perokok dunia dan 20\% penyebab kematian global akibat tembakau. Persentase perokok pada penduduk di Negara ASEAN tersebar di Indonesia 46,16\%, Filipina 16,62\%, Vietnam 14,11\%, Myanmar 8,73\%, Thailand 7,74\%, Malaysia 2,90\%, Kambodja 2,07\%, Laos 1,23\%, Singapura 0,39\%, dan Brunei 0,04\%. Di Indonesia sendiri, terdapat 5 provinsi proporsi tertinggi terkait konsumsi rokok yakni Provinsi Kepulauan Riau (27,1\%), Bengkulu (27,1\%), Jawa Barat $(27,1 \%)$, NTB $(21,1 \%)$, dan Gorontalo $(26,8 \%)$ 
(Depkes.2016).

Prevalensi orang merokok dikalangan orang dewasa meningkat menjadi 31,5 \% pada tahun 2001 dari $26,9 \%$ pada tahun 1995. Hanya 1,3\% wanita dilaporkan merokok secara teratur pada tahun 2001. Dengan demikian, hampir satu dari tiga orang dewasa merokok dan sebagian besar perokok tersebut adalah laki-laki. Pada tahun 2001, diketahui $62,2 \%$ dari pria dewasa merokok, angka tersebut meningkat bila dibandingkan tahun 1995, dimana 53,4\% pria dewasa adalah prokok. Prevalensi merokok dikalangan pria dewasa di pedesaan $(67,0 \%)$ lebih tinggi dari perkotaan $(58,3 \%)$. Tujuh puluh tiga persen dari perokok tersebut berpendidikan tidak formal. Di Indonesia, merokok telah menyebabkan kematian sebanyak 5 juta orang per tahunnya. Jika hal ini terus berlangsung, diperkirakan jumlah kematian akibat merokok akan meningkat hingga mendekati 10 juta orang per tahun pada tahun 2020 (Suparmin S.2010)

Berdasarkan penelitian-penelitian sebelumnya dijelaskan bahwa beban penyakit akibat rokok antara lain penyakit kardiovaskular, kanker, penyakit pernafasan, mengganggu kehamilan, ulkus peptik, osteoporosis dan sebagainya. Selain beban penyakit yang ditanggung oleh perokok itu sendiri, dikatakan dalam jurnal The Smoking Impact on Health bahwa angka kematian yang disebabkan oleh kebiasaan merokok dari remaja sangatlah signifikan, terbukti dari beberapa penelitian yang mengatakan erat kaitannya antara kebiasaan merokok dengan penyakit-penyakit yang ada di tubuh manusia (Vineis.P.2008). Penyakitpenyakit yang diakibatkan oleh kebiasaan merokok dari usia remaja sangatlah banyak antara lain penyakit kardiovaskuler, kanker. Bahkan akhirakhir ini dikatakan bahwa merokok dapat meninigkatkan resiko terjadinya diabetes melitus tipe 2 (Targher.2005).

Diabetes melitus tipe 2 sendiri mempunyai karakteristik glukosa dalam darah yang tinggi diakibatkan karena kelainan sekresi insulin, kerja insulin atau keduanya (Perkeni.2015). Glukosa sendiri merupakan sumber energi utama bagi sel manusia. Glukosa terbentuk dari karbohidrat yang dikonsumsi melalui makanan dan disimpan sebagai glikogen di hati dan otot. Kadar glukosa darah dipengaruhi oleh faktor eksogen dan endogen. Faktor eksogen yaitu jenis dan jumlah makanan yang dikonsumsi serta aktivitas yang dilakukan. Sedangkan faktor endogen antara lain humoral factor seperti glukagon, kortisol dan insulin (Lestari.2013).

Salah satu faktor endogen yang berperan penting dalam mempengaruhi kadar glukosa yakni insulin. Jika sekresi dan kerja insulin terganggu, maka akan 
mengakibatkan peningkatan kadar glukosa dalam darah. Banyak penelitian yang mengatakan bahwa kandungan pada rokok yakni nicotine sangatlah berperan dalam proses terjadinya resistensi insulin. Bermula dari aktivasi hormon katekolamine sehingga mempengaruhi penurunan pelepasan insulin, pengaruh negatif pada kerja insulin, gangguan pada sel beta pankreas dan perkembangan kearah resistensi insulin (Ario Dwi. 2014). Pada penelitian sebelumnya juga dikatakan bahwa pada 32 pria bukan perokok dan 32 pria perokok terdapat perbedaan jumlah kadar glukosa darah puasa yakni nilai rerata kadar glukosa darah puasa pada kelompok bukan perokok adalah 102,0 $\mathrm{mg} / \mathrm{dL}$, sedangkan nilai rerata kadar glukosa pria perokok adalah 118,6 mg/dL (Suparmin S.2010). Oleh karena itu telah kita ketahui bersama berdasarkan penjelasan diatas menghisap rokok sangatlah berbahaya, dapat menimbulkan banyak penyakit.

Tidak merokok, berhenti merokok serta menghindarkan diri dari asap rokok merupakan cara untuk menghindari diri dari penyakit-penyakit yang ditimbulkan akibat merokok. Salah satunya yakni penyakit diabetes mellitus dikarenakan rusaknya sel $\beta$ pankreas ataupun terganggunya kerja insulin yang di akibatkan oleh kandungan nikotin pada rokok. Sehingga bukan hanya mahasiswa sendiri yang berperan untuk menghindarkan diri dari bahaya rokok tersebut, melainkan menciptakan kehidupan kampus yang bebas dari asap rokok juga sangat berperan untuk membantu mahasiswa terhindar dari bahaya merokok tersebut.

Merujuk uraian diatas, peneliti sebagai mahasiswa Fakultas Kedokteran Universitas Islam Al-Azhar Mataram sangat berkeinginan untuk memberikan perhatian khusus pada perilaku kebiasaan merokok dan pengaruhnya pada kesehatan dengan menyusun sebuah penelitian yang nantinya berfokus pada jumlah batang rokok yang di hisap dengan perubahan kadar glukosa darah pada Perokok Aktif Mahasiswa Fakultas Hukum Universitas Islam Al-Azhar Mataram tahun 2019 yang berjumlah 52 Orang Peorkok Aktif.

\section{METODE PENELITIAN}

\section{Jenis dan Rancangan}

Jenis penelitian yang digunakan pada penelitian ini adalah Quasi Experimet Design dengan rancangan Non Equivalent Control Group. Non Equivalent Control Groupadalah rancangan mempunyai kelompok pembanding (kontrol) namun kelompok pembanding boleh tidak benarbenar sama dan pengambilan sampel pada kelompok eksperimen ataupun control tidak dilakukan secara random atau acak. Pada rancangan penelitian ini juga sudah dilakukan observasi pertama (pretest) yang memungkinkan peneliti dapat 
menguji perubahan yang terjadi setelah adanya ekperimen (posttest) (Notoatmodjo, 2014).

Rancangan Non Equivalent Control Group terdapat pretest $\left(\mathrm{O}_{1}\right)$ sebelum diberikan perlakuan (X), dan kemudian dilakukan pengukuran atau posttest $\left(\mathrm{O}_{2}\right)$ setelah perlakuan, sebaliknya pada kontrol dilakukan pretest dan posttest tanpa adanya perlakuan (X), sehingga hasil dapat dibandingkan antara kontrol dengan eksperimen(Notoatmodjo, 2014).

Perlakuan yang diberikan pada kelompok eksperimen berupa pemberian rokok sejumlah 2 batang dan pada kontrol tidak diberikan. Kemudian kedua kelompok diperiksa kadar glukosa darah sebelum dan sesudah intervensi. Alasan peneliti memilih jenis penelitian ini adalah untuk mengetahui pengaruh rokok terhadap kadar glukosa darah denganadanya pembanding berupa variabel kontrol. Untuk menentukan bahwa hasil posttest yang di peroleh pada akhir penelitian merupakan akibat dari intervensi, maka peneliti membatasi karakteristik responden dengan beberapa kriteria.Rancangan penelitian dapat digambarkan dalam bagan berikut:

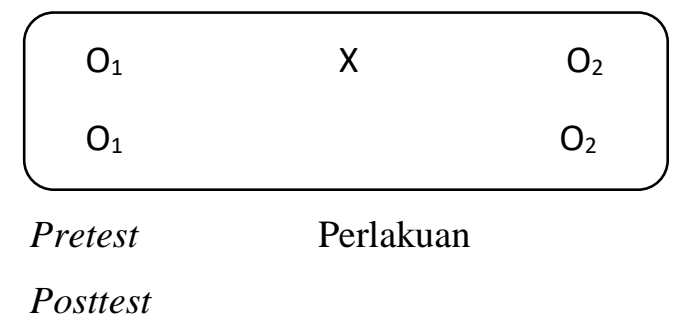

Keterangan :
$\mathrm{O}_{1}=$ Pretest (pemeriksaan kadarglukosa darah sebelum intervensi).

$\mathrm{X}=$ Perlakuan (jalan santai).

$\mathrm{O}_{2}=$ Posttest (pemeriksaan kadar glukosa darah setelah intervensi).

\section{TEMPAT dan WAKTU}

\section{Tempat Penelitian}

Penelitian ini dilakukan di Fakultas Hukum Universitas Islam Al-Azhar Mataram.

\section{Waktu Penelitian}

Penelitian inidilakukan pada bulan Februari 2019.

\section{POPULASI dan SAMPEL}

\section{Populasi}

Populasi pada penelitian ini adalah mahasiswa perokok aktif Fakultas Hukum Universitas Islam Al-Azhar Mataram periode 2015 - 2019 yang berjumlah 109, terdiri dari 74 orang Laki-Laki dan 35 orang Perempuan serta terdapat 52Orang Perokok Aktif Laki-Laki.

\section{Sampel}

Dalam penelitian ini, teknik pengambilan sampel menggunakan caratotal sampling, yaitu pengambilan sampel yang sama dengan jumlah populasi yang ada (Ari Kunto.2016).

Populasi yang dimaksudkan peneliti disini adalah populasi perokok aktif yang berjumlah 52 orang. Diambil menggunakan teknik total sampling dikarenakan jumlah sampel kurang dari 
100 (Sugiyono.2007). Sampel selanjutnya dibagi menjadi dua kelompok yakni 26orang kelompok eksperimen dan 26 orang kelompok kontrol.

\section{PEMILIHAN SUBJEK PENELITIAN}

\section{Kriteria Inklusi}

Kriteria inklusi pada penelitian ini yaitu:

1. Bersedia mengikuti prosedur penelitian.

2. Perokok Aktif yakni orang yang merokok >100 batang semasa hidupnya.

\section{Kriteria Eksklusi}

Kriteria eksklusi pada penelitian ini yaitu:

1. Melakukan aktivitas fisik sebelum penelitian antara lain olahraga, angkat beban.

2. Mengkonsumsi teh, kopi, dan alkohol selama penelitian berlangsung.

3. Mempunyai penyakit hepar, diabetes melitus.

\section{VARIABEL dan DEFINISI \\ OPERASIONAL}

\section{Variabel}

1. Variabel bebas (Independent) penelitian ini adalah merokok.

2. Variabel terikat (dependent) penelitian ini adalah kadar glukosa darah.

\section{Definisi Operasional}

Definisi operasional pada penelitian ini, yaitu:

1. Merokok adalah orang yang merokok dan langsung menghisap rokokdengan jumlah 2 batang.
2. Kadar Glukosa Darah adalah hasil pengukuran glukosa darahsewaktu pada 0 menit dan 30 menit setelah dilakukannya intervensi

\section{Instrumen dan Bahan}

Alat dan bahan pada penelitian ini adalah:

1. Lembar Persetujuan Responden

2. Kuesioner

3. Rokok kretek

4. Glukometer

5. Lancet

6. Alcohol pad

7. ATK

8. Kertas HVS A4

\section{Cara Kerja Penelitian}

Cara kerja penelitian ini adalah sebagai berikut:

1. Peneliti meminta persetujuan subjek penelitian dengan mengisi dan menandatangani formulir informed consent;

2. Menilai apakah subjek termasuk ke dalam kriteria inklusi atau eksklusi.

3. Jika subjek termasuk ke dalam kriteria inklusi maka subjek selanjutnya dilakukan penilaian kadar glukosa darah sebelum intervensi. Dengan teknik sebagai berikut :

- Menyiapkan perangkat glucometer yaitu uji strip, lancet, dan alkohol pad;

- Mencuci tangan dengan cairan antiseptik dan memakai handscoon untuk mencegah infeksi; 
- Membersihkan daerah yang akan ditusuk (jari ketiga atau jari keempat) dengan alcohol pad, diamkan sebentar sampai mengering;

- Menusuk jari dengan lancet, lalu ambil satu tetes darah untuk diperiksa, tunggu beberapa saat sampai hasil keluar;

- Mencatat hasil pada lembar data penelitian.

4. Melakukan Intervensi berupa pemberian rokok yang berjumlah dua batang kepada kelompok eksperimen dan tanpa pemberian rokok pada kelompok kontrol.

5. Mengukur kembali kadar glukosa darah 30 menit setelah subjek menghisap 2 batang rokok kretek.

6. Melakukan pengolahan data

7. Melakukan analisis data dengan tahapan editing, coding dan entry. Pada tahap anlisis data, peneliti memakai rumus Uji Chi Squareyang kemudian dimasukkan kedalam program computer SPSS.

8. Peneliti memperoleh hasil.

9. Peneliti melaporkan hasil.

\section{HASIL DAN PEMBAHASAN}

\section{Hasil Penelitian}

Penelitian ini adalah penelitian yang dilakukan pada mahasiswa perokok aktif Fakultas Hukum Universitas Islam AlAzhar Mataram. Teknik pengambilan sampel yang digunakan adalah total sampling, dengan jumlah populasi sebanyak 52 orang perokok aktif dengan 26 kelompok eksperimen dan 26 kelompok kontrol. Penelitian ini dilakukan selama 2 hari, yaitu pada tanggal11-12 Februari 2019.

\section{ANALISIS UNIVARIAT}

\section{Karakteristik Responden Berdasarkan}

Usia

Berdasarkan hasil penelitian, dari total responden eksperimen sebanyak 26 orang perokok aktif didapatkan bahwa sebagian besar usia responden 21-22 orang (50\%), responden dengan usia 19 tahun sebanyak 7 orang $(26,9 \%)$ dengan usia termuda yakni 19 tahun, dan responden dengan usia 23-24 tahun sjumlah 6 orang dengan persentase $(23,1 \%)$ usia tertua yakni 23 tahun. Sedangkan pada 26 responden pada kelompok kontrol didapatkan bahwa responden kelompok kontrol memiliki usia 19-20 tahun dan 21-22 tahun masingmasing sebanyak 11 orang $(42,3 \%)$ dengan usia termuda yakni 19 tahun dan usia tertua yakni 24 tahun.

\section{Karakteristik Responden Berdasarkan}

\section{Lama Merokok}

Berdasarkan hasil penelitian, dari total responden eksperimen sebanyak 26 orang perokok aktif didapatkan bahwa sebagian besar responden merokok <5 tahun sebanyak 13 orang (50\%) dengan rentang merokok terpendek yakni 3 tahun, 
responden yang merokok 5-10 tahun sebanyak 10 orang $(38,5 \%)$, dan responden yang merokok>10 tahun didapatkan sebanyak 3 orang dengan persentase $11,5 \%$ dengan rentang merokok terlama yakni 14 tahun. Sedangkan pada 26 responden pada kelompok kontrol didapatkan bahwa sebagian besar responden kelompok kontrol merokok dengan rentang waktu 5-10 tahun sebanyak 12 orang $(46,2 \%)$ dan 10 orang $(38,5 \%)$ merokok dengan kurun waktu $<5$ tahun serta didapatkan 4 orang $(15,3 \%)$ merokok lebih dari 10 tahun.

Karakteristik Responden berdasarkan jumlah batang rokok yang dihisap.

Berdasarkan hasil penelitian, dari total 26 responden kontrol dan 26 responden eksperimen didapatkan bahwa seluruh responden menghisap rokok $>100$ batang semasa hidupnya.

\section{Karakteristik Responden Berdasarkan}

\section{Status Merokok}

Berdasarkan hasil penelitian, dari total 26 responden eksperimen didapatkan bahwa mayoritas perokok aktif merpakan perokok setiap hari yakni sebanyak 25 orang $(96,2 \%)$ dan didapatkan 1 orang $(3,8 \%)$ perokok beberapa kali.Sedangkan pada 26 responden kelompok kontroldidapatkan juga mayoritas perokok setiap hari yakni sebanyak 24 orang $(92,3 \%)$ dan 2 orang $(7,7 \%)$ perokok beberapa kali.
Karakteristik Responden berdasarkan

\section{Derajat Merokok}

Berdasarkan hasil penelitian, dari total 26 responden eksperimen didapatkan bahwa perokok sedang memiliki jumlah dan persentase terbanyak yakni 14 orang $(53,8 \%)$ diikuti jumlah perokok ringan yakni 12 orang $(46,2 \%)$. Sedangkan pada 26 responden kontrol didapatkan persebaran responden berdasarkan derajat merokok yakni 15 orang $(57,7 \%)$ perokok sedang dan 11 orang (42,3\%) perokok sedang.

\section{Karakteristik Responden berdasarkan} Jenis Rokok

Berdasarkan hasil penelitian, dari total 26 responden kontrol dan 26 responden eksperimen didapatkan bahwa seluruh responden memiliki jenis rokok yang sama yakni rokok kretek dengan dilter, kemungkinan seluruh reponden merokok jenis ini dikarenakan harganya yang murah dan rokok jenis ini merupakan rokok yang sangat umum kita jumpai di Indonesia.

\section{Karakteristik Responden Berdasarkan Kadar Glukosa Darah Sebelum Intervensi}

Berdasarkan hasil penelitian, dari total responden eksperimen sebanyak 26 orang perokok aktif didapatkan bahwa sebanyak 14 orang $(53,8 \%)$ dengan kadar glukosa $101-140,10$ orang $(38,5 \%)$ dengan kadar glukosa 77-100 dengan kadarterendah yakni $77 \mathrm{mg} / \mathrm{dL}$ dan hanya 
2 orang $(7,7 \%)$ dengan kadar glukosa 141188 dengan nkadar tertinggi yakni 150 $\mathrm{mg} / \mathrm{dL}$. Mayoritas responden eksperimen dengan kadar glukosa 101-140 kemungkinan karena pengecekan kadar glukosa darah sewaktu di pagi hari, sehingga memungkinkan responden sudah sarapan atau mengkonsumsi makanan dan minuman yang dapat menambah kadar glukosa darah sebelum menuju lokasi penelitian. Sedangkan pada 26 orang responden kontrol didapatkan bahwa kadar glukosa terbanyak yakni pada rentang 101-140 sebanyak 16 orang $(61,6 \%), 5$ orang $(19,2 \%)$ dengan kadar glukosa 77-100 dengan kadar terendah yakni $83 \mathrm{mg} / \mathrm{dL}$ dan 5 orang $(19,2 \%)$ dengan kadar glukosa 141-188 dengan kadar tertinggi yakni 188 mg/dL.

\section{Karakteristik Responden Berdasarkan}

\section{Kadar Glukosa Darah Sesudah}

\section{Intervensi}

Berdasarkan hasil penelitian, dari total responden eksperimen sebanyak 20 orang perokok aktif didapatkan bahwa sebanyak 16 orang $(61,6 \%)$ dengan kadar glukosa 101-140, 5 orang $(19,2 \%)$ dengan kadar glukosa 77-100 dengan nilai terendah yakni $85 \mathrm{mg} / \mathrm{dL}$ dan 5 orang $(19,2 \%)$ dengan kadar glukosa 141-188 dengan nilai tertinggi yakni $152 \mathrm{mg} / \mathrm{dL}$. Mayoritas responden eksperimen dengan kadar glukosa darah 101-140 kemungkinan karena efek nikotin terhadap kadar glukosa darah, hal ini sesuai dengan penelitian yang dilakukan oleh Suparmin S (2010). Sedangkan pada 26 orang responden kontrol didapatkan bahwa kadar glukosa terbanyak yakni pada rentang 101-140 sebanyak 16 orang $(61,6 \%), 7$ orang $(26,9 \%)$ dengan kadar glukosa 77-100 dengan kadar terendah yakni $78 \mathrm{mg} / \mathrm{dL}$ dan 3 orang $(11,5 \%)$ dengan kadar glukosa 141-188 dengan kadar tertinggi yakni $177 \mathrm{mg} / \mathrm{dL}$. Mayoritas responden kontrol memiliki kadar glukosa darah pada rentang 101140.

\section{ANALISIS BIVARIAT}

Rerata kadar glukosa darah perokok aktif (Eksperimen dan Kontrol)

Berdasarkan hasil penelitian, dari total 26 responden perokok aktif pada kelompok eksperimen didapatkan bahwa sebanyak 18 orang dengan kadar glukosa darah sewaktu meningkat setelah dilakukan perlakuan berupa 2 batang rokok dan pengecekan kadar glukosa darah pada 30 menit setelah perlakuan, 1 orang ditemukan tidak terdapat perubahan dan 7 orang lagi ditemukan menurun.

Sedangkan pada 20 responeden perokok aktif kelompok kontrol didapatkan hasil penurunan kadar glukosa darah saat pengecekan pada menit ke 30 menit (posttest), pada 6 responden kelompok kontrol ini dijumpai juga peningkatan kadar glukosa darah saat pengecekan pada menit ke 30 (posttest), 
keadaan peningkatan kadar glukosa darah sewaktu pada kelompok kontrol ini mungkin diakibatkan karena pada saat penelitian ada beberapa responden yang meninggalkan lokasi penelitian setelah dilakukannya pretest, dan kembali lagi 30 menit setelah pretest, hal ini memungkinkan responden kemungkinan mengkonsumsi makanan atau minuman yang mempengaruhi peningkatan kadar glukosa darah sewaktu.

Peningkatan kadar glukosa darah setelah intervensi berupa 2 batang rokok pada kelompok eksperimen sesuai dengan penelitian yang dilakukan oleh Ario Dwi (2014) dan Suparmin S (2010). Keduanya mengatakan bahwa terdapat pengaruh nikotin terhadap pemningkatan kadar glukosa darah. Pada penelitian ini kemungkinan didapatkan peningkatan dikarenakan jumlah batang rokok dan waktu posttest yang memungkinkan nikotin beredar didalam darah dan mempengaruhi insulin sehingga dapat berpengaruh tehadap kadar glukosa darah sewaktu.

\section{Hasil UjiChi-Square}

Berdasarkan tabel di atas dapat dilihat bahwa jumlah sampel peneliti 52 orang dengan persentase $100 \%$, tidak terdapat kesalahan pemasukan dataserta semua data sudah dimasukkan ke dalam program SPSS dengan benar.

Hasil Uji Chi-Square memberikan nilai $p$ value sebesar 0,001 dapat dilihat pada tabel Pearson Chi-Square. Sehingga terdapat hubungan yang signifikan diantara kedua kelompok, yakni didapatkan peningkatan kadar glukosa darah pada kelompok intervensi. Sehingga terdapat perbedaan yang signifikan antarapretest dan posttest.

Terdapat perbedaan yang signifikan pada penelitian ini sesuai dengan penelitian Ario Dwi (2014) yang mengatakan bahwa kandungan pada rokok yakni nicotine sangatlah berperan dalam proses terjadinya resistensi insulin. Bermula dari aktivasi hormon katekolamine sehingga mempengaruhi penurunan pelepasan insulin, pengaruh negatif pada kerja insulin, gangguan pada sel beta pankreas dan perkembangan kearah resistensi insulin. Hal ini juga dibuktikan dalam penelitian Suparmin S (2010) bahwa dibutuhkan terapi insulin yang banyak pada 32 pria perokok dibandingkan pada pria bukan perokok.

\section{PEMBAHASAN PENELITIAN}

\section{Usia}

Berdasarkan hasil penelitian, dari total responden eksperimen sebanyak 26 orang perokok aktif didapatkan bahwa sebagian besar usia responden 21-22 orang (50\%), responden dengan usia 19 tahun sebanyak 7 orang $(26,9 \%)$ dengan usia terendah yakni 19 tahun, dan responden dengan usia 23-24 tahun sjumlah 6 orang dengan persentase $(23,1 \%)$ usia tertinggi 
yakni 23 tahun. Sedangkan pada 26 responden pada kelompok kontrol didapatkan bahwa responden kelompok kontrol memiliki usia 19-20 tahun dan 2122 tahun masing-masing sebanyak 11 orang $(42,3 \%)$ dengan usia termuda yakni 19 tahun dan usia tertua yakni 24 tahun.

Usia tertua yakni 24 tahun, berdasarkan wawancara, banyak faktorfaktor yang mempengaruhi lama studi mahasiswa Fakultas Hukum Universitas Islam Al-Azhar Mataram, beberapa diantaranya yakni berdasarkan pengakuan responden pada saat wawancara bahwa hal tersebut diakibatkan responden memiliki riwayat organisasi yang padat dan usia responden ketika memasuki Fakultas Hukum terlambat 1 tahun.

\section{Lama Merokok}

Berdasarkan hasil penelitian, dari total responden eksperimen sebanyak 26 orang perokok aktif didapatkan bahwa sebagian besar responden merokok $<5$ tahun sebanyak 13 orang (50\%) dengan rentang merokok terpendek yakni 3 tahun, responden yang merokok 5-10 tahun sebanyak 10 orang $(38,5 \%)$, dan responden yang merokok >10 tahun didapatkan sebanyak 3 orang dengan persentase $11,5 \%$ dengan rentang merokok terlama yakni 14 tahun. Sedangkan pada 26 responden pada kelompok kontrol didapatkan bahwa sebagian besar responden kelompok kontrol merokok dengan rentang waktu 5-10 tahun sebanyak 12 orang $(46,2 \%)$ dan 10 orang $(38,5 \%)$ merokok dengan kurun waktu $<5$ tahun serta didapatkan 4 orang $(15,3 \%)$ merokok lebih dari 10 tahun.

Pada kelompok eksperimen maupun kelompok kontrol didapatkan jumlah perokok yang merokok $<5$ tahun merupakan responden terbanyak, hal ini dikarenakan karena pengaruh lingkungan responden, rata-rata responden merokok pada bangku Sekolah Menengah Atas (SMA). Selain lingkungan sekolah, kemungkinan lingkungan tempat tinggal dari responden juga sangat berpengaruh, ditemukan bahwa sebagian besar responden berasal dari luar kota Mataram, yakni Lombok Utara, Lombok Tengah, Lombok Barat dan Lombok Timur. Kemungkinan dilingkungan responden masih belum terlalu memahami akan bahaya merokok terhadap kesehatan.

\section{Jumlah Rokok yang Dikonsumsi Selama Hidup dan Status Merokok}

Berdasarkan hasil penelitian, dari total 26 responden eksperimen didapatkan bahwa mayoritas perokok aktif merpakan perokok setiap hari yakni sebanyak 25 orang $(96,2 \%)$ dan didapatkan 1 orang $(3,8 \%)$ perokok beberapa kali. Sedangkan pada 26 responden kelompok kontrol didapatkan juga mayoritas perokok setiap hari yakni sebanyak 24 orang $(92,3 \%)$ dan 2 orang $(7,7 \%)$ perokok beberapa kali.

Perokok setiap hari merupakan responden yang terbanyak pada penelitian 
ini, hal ini kemungkinan dikarenakan responden jauh dari pengawasan orang tua, pergaulan responden, dan pengaruhpengaruh lainnya yang memungkinkan responden untuk merokok setiap hari. Hal ini juga dikarenakan efek nikotin yang mempengaruhi produksi dopamin sehingga menimbulkan efek kecanduan sehingga memungkinkan responden untuk merokok setiap hari.

\section{Jenis Rokok}

Berdasarkan hasil penelitian, didapatkan bahwa seluruh responden mengonsumsi rokok jenis kretek dengan filter, dengan jumlah 52orang dan persentase $100 \%$ dengan 26 kelompok

Eksperimen dan 26 kelompok kontrol. Perbedaan rokok kretek yang berfilter atau tanpa filter adalah adanya semacam busa penyaring pada salah satu ujung rokok kretek dengan filter. Rokok kretek banyak dikonsumsi kemungkinan karena menurut responden memiliki cita rasa yang khas dibandingkan dengan rokok putih atau jenis rokok lainnya.

\section{Keterbatasan Penelitian}

Dalam pelaksanaan penelitian terdapat beberapa keterbatasan seperti :

1. Karya tulis ilmiah ini terbatas pada jumlah batang rokok yang dihisap tanpa melihat adanya faktor yang dapat mempengaruhi data GDS yang didapat dari responden.
2. Jumlah responden pada karya tulis ilmiah ini kurang memadai akibat tempat dilakukannya penelitian hanya terbatas pada satu fakultasdengan jumlah perokok yang tidak terlalu banyak.

3. Metode penelitian yang hanya melakukan pengukuran sesaat sehingga memungkinkan data yang didapat peneliti sebelum dan sesudah intervensi tidak begitu berubah signifikan.

4. Jadwal kegiatan penelitian ini pada saat libur semester, sehingga menyulitkan peneliti untuk mengumpulkan responden.

\section{SIMPULAN DAN SARAN}

\section{SIMPULAN}

Setelah dilakukan penelitian tentang hubungan merokok dengan kadar glukosa darah mahasiswa Fakultas Hukum Universitas Islam Al-Azhar Mataram Tahun 2019, dapat disimpulkan bahwa :

1. Rerata kadar glukosa darah pretest dan posttest pada kelompok eksperimen adalah $107,73 \mathrm{mg} / \mathrm{dL}$ dan 112,65 $\mathrm{mg} / \mathrm{dL}$.

2. Rerata kadar glukosa darah pretest dan posttest pada kelompok kontrol adalah $123,27 \mathrm{mg} / \mathrm{dL}$ dan $112,40 \mathrm{mg} / \mathrm{dL}$.

3. Terdapathubungan yang signifikan antara merokok dengan kadar glukosa darah sebelum dan sesudah intervensi pada mahasiswa Fakultas Hukum 
Universitas Islam Al-Azhar Mataram

Tahun 2019 dengan $P$ value $=0,001$

$(p<0,05)$.

\section{SARAN}

\section{Bagi Bidang Kesehatan}

Diharapkan bagi bidang kesehatan agar dapat digunakan sebagai bahan edukasi tentang bahaya merokok bagi kesehatan sehingga masyarakat lebih sadar akan dampak yang ditimbulkan rokok terhadap kesehatan.

\section{Bagi Peneliti Selanjutnya}

Sebagai bahan pertimbangan penelitian selanjutnya, sebaiknya peneliti juga menggunakan jumlah sampel yang lebih banyak, jumlah batang rokok pada saat intervensi yang lebih banyak, serta menggunakan metode yang lebih kuat seperti True Experiment.

\section{Bagi Masyarakat}

Diharapkan setelah dilakukannya penelitian ini masyarakat mempunyai pengetahuan tentang bahaya merokok bagi kesehatan sehingga masyarakat paham mengenai pentingnya tidak merokok, berhenti merokok atau tidak terpapar dengan asap rokok.

\section{DAFTAR PUSTAKA}

Alamsyah,R. 2009. Faktor-Faktor yang Mempengaruhi Kebiasaan Merokok dan Hubungannya dengan Status Penyakit Periodontal Remaja di Kota Medan Tahun 2007 (Thesis). Medan : Universitas Sumatra Utara.

Amin M. 2010. Departemen Ilmu Penyakit Paru. Departemen Ilmu Penyakit
Paru FK Unair RSUD Dr. Soetomo : Surabaya

American Diabetes Association (ADA). 2014. Diagnosis and Classification of Diabetes Mellitus. Diabetes Care.

Ario Dwi. 2014. Effect Of Nicotine In Cig arette For Type 2 Diabetes Mellitu s. http://juke.kedokteran.unila.ac.id /index.php/majority/article/viewFil e/481/482. Diakses 4 oktober 2018.

Arikunto, Suharsimi.2010.Prosedur Penelitian.Jakarta : Rineka Cipta.

Bernard, A. S.Kerure, S. B. 2013. Glucose Handling during Menstrual Cycle. International Journal of Reproduction, Obstetrics and Gynecology.

Depkes RI.2016.Perilaku Merokok Masyarakat Indonesia Berdasarkan RISKESDAS 2007 dan 2013. Jakarta : Badan Penelitian dan Pengembangan Kesehatan DEPKES RI.

Departemen Kesehatan Republik Indonesia. 2013. Riset Kesehatan Dasar. http://www.depkes.go.id/res ources/download/general/Hasil\%20 Riskesdas\%202013. Diakses Tanggal 4 Oktober 2018.

De borba. Andresa Their. Jost. Renan Tre vison. Gass. Ricardo. Nedel. Fulvo Borges. Cardoso. Danneuey Macha do. Pohl. Hildegard Hedwig. Reckz iegel. Miarm Beatris. Corbellini. V aleriano Antonio. Paiva,Dulcaine N unes.2014. The Influence of active and Passive smoking on the cardior espiratory Fitness of Adult.https:// www.ncbi.nlm.nih.gov/pmc/article s/PMC4088222/pdf/2049-6958-934.pdf. Diakses tgl 4 oktober 2018.

Guyton, C. Arthur dan Hall. John E. 2007. Buku Ajar Fisiologi Kedokteran Edisi 11. Jakarta: EGC.

Hammond David. Callard Cynthia. Collishaw. 2006. Secret science: Tobacco industry research on smoking behaviour and cigarette 
toxicity.Departement of Helath Stu dies University of Waterloo Canad a. https://www.researchgate.net/pu blication/7261340_Secret_science_ Tobacco industry research on sm oking_behaviour_and_cigarette_to xicity. Diakses tanggal 4 oktober 2018.

Hasan, M. Iqbal.2002. Pokok-pokok Materi Metodologi Penelitian dan Aplikasinya. Bogor : Ghalia Indonesia.

Katzung. Bertram G. 2010. Farmakologi Dasar dan Klinik. Edisi 10. Jakarta: EGC.

Lestari,D.D.,Purwanto.D.S, \& Kaligis, S.H.M. 2013. Gambaran Kadar Glukosa Darah Puasa pada Mahasiswa angkatan 2011 Fakultas Kedokteran Universitas Samratulangi dengan indeks masa tubuh 18,5-22,9 $\mathrm{kg} / \mathrm{m}^{2}$. Manado : Jurnal Ebm FK UNSRA T.https://ejournal.unsrat.ac.id/index .php/ebiomedik/article/view/3308. Diakses tanggal 4 oktober 2018.

Marianti. Aditya. 2009. Aktivitas Antioksidan Jus Tomat pada pencegahan kerusakan jaringan paru-paru Mencit yang Dipapar Asap Rokok. Jurusan Biologi FMIPA Universitas Negeri Semarang.

Murray. Robert K. Granner. Daryl K. Rodwell. Victor W. 2009.Biokimia Harper Edisi 27. Jakarta: EGC.

Notoatmodjo,S. 2012. Metodologi Penelitian Kesehatan. Jakarta: Rineka Cipta.

PERKENI. 2015. Konsensus Pengelolaan dan Pencegahan Diabetes Melitus Tipe 2 di Indonesia 2015. https://puskespemda.net/dow nload/konsensus-dm-2015/.

Diakses Tanggal 4 Oktober 2018.

POM RI. 2015. Keracunan yang Disebab kan Gas Karbon Monoksida. https:/ /www.pom.go.id/mobile/index.php/ view/berita/76/Keracunan-yangDisebabkan-GasKarbon-Monoksida.html. Diakses Tanggal 04 okt 2018.

PP RI 109 TH 2012. Pengamanan Bahan yang Mengandung Zat Adiktif Berupa Produk Tembakau Bagi Kesehatan. http://si puu.setkab.go.id/PUUdoc/173643/ PP1092012.pdf. Diakses Tanggal 4 OKT 2018.

Sastroasmoro, S. 2011. Dasar-Dasar Metodologi Penelitian Klinis. Jakarta : Sagung Seto.

Setiawati A, Gan S. 2007. Farmakologi dan Terapi. Jakarta: FK UI.

Sherwood. Lauralee. 2011. Fisiologi Manusia dari Sel ke Sistem Edisi 6. Jakarta: EGC.

Sitepoe,M. 2000. Kekhususan Rokok Indonesia. Jakarta : PT Grasindo.Sugiyono. 2007. Metode Penelitian Kuantitatif Kualitatif dan $R \& D$. Bandung : Alfabeta

Suparmin S. 2010. Beda kadar glukosa darah pada pria perokok dan buka perokok tembakau usia 20-60 tahun di salemba tahun 2009-2010. Jakarta: FK UI.

Targher G. 2005. How Does Smoking Affect Insulin Sensitivity. Diabetes Voice. Volume 50.

Vineis P. 2008. Smoking Impact on Healt h. https://pdfs.semanticscholar.org/ 42d2/b8f32ff6298add2031a3aff24d a29bcc0c06.pdf. Dikses Tanggal 4 Oktober 2018 